\title{
Thermoanalytical and Starch Content Evaluation of Cassava Bagasse as Agro-Industrial Residue
}

\author{
Luiz Gustavo Lacerda ${ }^{1}$, Rafael Ramires Almeida ${ }^{2}$, Ivo Mottin Demiate ${ }^{2}$, Marco Aurélio \\ Silva Carvalho Filho ${ }^{3}$, Eliane Carvalho Vasconcelos ${ }^{3}$, Adenise Lorenci Woiciechowski ${ }^{1}$, \\ Gilbert Bannach $^{2}$, Egon Schnitzler ${ }^{2}$ and Carlos Ricardo Soccol ${ }^{*}$ \\ ${ }^{1}$ Divisão de Engenharia de Bioprocessos e Biotecnologia; Universidade Federal do Paraná; C. P.: 19011; 81531- \\ 990; Curitiba - PR - Brasil. ${ }^{2}$ Departamento de Engenharia de Alimentos; Universidade Estadual de Ponta Grossa; \\ Av. Carlos Cavalcanti, 4748; 84030-900; Ponta - Grossa - PR - Brasil. ${ }^{3}$ Departamento de Pesquisa Universidade \\ Positivo; Av. Prof. Pedro Viriato Parigot de Souza, 5300; 81280-330; Curitiba - PR - Brasil
}

\begin{abstract}
Starch nutritional fractions as well as thermal properties and other analysis are essential for food and industrial application. Cassava bagasse is an important agro-industrial residue and its starch content was evaluated using two alternative methods. Thermal characterization and microscopy analyses helped to understand how hydrolysis digests starchy fraction of cassava bagasse. The melting point of cassava starch occurred at $169.2^{\circ} \mathrm{C}$. Regarding $T G$ analyses, after moisture content, there were observed two main mass losses for all samples. Results suggest hydrolysis carried out using enzyme is less effective in order to convert total starch content in cassava bagasse. However, using sulfuric acid, fibers are affected by analyses conditions.
\end{abstract}

Key words: amylase, cassava, hydrolysis, thermal analysis

\section{INTRODUCTION}

Starch market comes growing in the last years, leading to the search of products with specific characteristics that support the requirements of the industry. The modified starch production is an alternative that is in continuous development to surpass one or more limitations of native starches and thus to increase the utility of this polymer for industrial applications (Lacerda et al., 2008; Leonel, Cereda and Roau, 1999; Rudnik et al., 2006; Wurzburg, 1986). Furthermore, there has been an increased exploitation of organic residues from various sectors of agriculture and industries over the past few decades. The use in biotechnological processes of crop residues such as bran, husk, bagasse, and fruit seeds regards as potential raw material in bioprocesses as they provide excellent substrates for the growth of microorganism supplying the essential nutrients to them (Pandey and Radhakrishnan, 1992; Pandey et al., 1994; Pandey and Soccol, 1998; Pandey et al., 2000). Their application in bioprocesses also offers advantages in bioremediation and biological detoxication of hazardous compounds (Ramachandran, 2000). Cassava (Manihot esculenta) ranks very high among crops that convert the greatest amount of solar energy and

\footnotetext{
* Author for correspondence: soccol@ufpr.br
} 
$\mathrm{CO}_{2}$ into carbohydrates per unit of area. Among the starchy staples, cassava gives a carbohydrate production which is about $40 \%$ higher than rice and $25 \%$ superior to corn, with the result that cassava is the cheapest source of calories for both human nutrition and animal feeding (Lacerda et al., 2008). Normally, $69 \%$ of the starches derived from the cassava are destined to nourishing use, in meat products, pastas, desserts, breads, biscuits, soups and candies. It has the remarkable capacity to adapt to various agro-ecological conditions. It is also considered as a low-risk crop (Pandey et al. , 2000). Cassava production is transformed into flour and starch, generating U\$ 600 million in flour and 150 million in starch. During starch extraction from cassava root, Leonel, Cereda and Roau (1999), highlighted that the amount of solid residues (mainly bagasses) generated is very great. Currently, bagasse is being donated to farmers for animal feeding, disposed in surrounding environment of processing units or sold for U\$ 5 per ton. The knowledge of starch content in cassava bagasse is very important once this residue can be used in further several industrial applications being a high value-added material. This study was performed to evaluate two usual methods for starch content determination in starchy material as well structural characterization using thermal analysis.

\section{MATERIALS AND METHODS}

\section{Samples}

Cassava bagasse was received from a Starch Industry (Comercial Agricola Anhumai) located in the Northwest Region of Parana State-Brazil. The material was dried and screened in order to obtain particles < $1 \mathrm{~mm}$. $\alpha$-amylase, from Bacillus licheniformis (Termamyl 240L), was acquired from Novozymes (Bagsvaerd, Denmark). Other reagents (i.e. sulfuric acid) were of analytical grade.

\footnotetext{
Hydrolysis

In order to solubilize starch content of cassava bagasse, it was adopted chemical and enzymatic hydrolyses as following description. For both situations, the experiments were conducted three times.
}

\section{Chemical Hydrolysis}

In this method, adapted from Woiciechovski (2000), 2.0g of dry cassava bagasse (moisture content of $10 \%$ ) were was added to $20.0 \mathrm{~mL}$ of distilled water and $2.0 \mathrm{~mL}$ of sulfuric acid in an erlenmeyer flask covered with aluminum foil paper and rubber band. Hydrolysis reaction was carried out in a water bath at approximately $98^{\circ} \mathrm{C}$ during $20 \mathrm{~min}$. After material cooling to room temperature (about $25^{\circ} \mathrm{C}$ ), the $\mathrm{pH}$ was adjusted to 7.0 using sodium hydroxide $0.5 \mathrm{~mol} / \mathrm{L}$. The total volume was completed to $100 \mathrm{~mL}$ with distilled water in a calibrated volumetric flask $( \pm 0.1 \mathrm{~mL})$. The aqueous medium was filtered in Whatman 42 filter paper and then an aliquot of $2.0 \mathrm{~mL}$ was separated. Reducing sugar content of the filtered solution, after a 1:10 (solution:water) dilution, was estimated with a spectrophotometer SHIMADZU UV-1601 at $540 \mathrm{~nm}$ following dinitrosalicilic (DNS) method (Miller, 1959; Tastun, 1970). This method involves spectrophotometric measurement of reducing sugar liberated from a known soluble starch medium by the action of amylase using dinitrosalicylic acid reagent at $\mathrm{pH} 6.9$ and room temperature (Milanh et al., 2008).

\section{Enzymatic hydrolysis}

In order to hydrolyse studied matter using $\alpha$ amylase in excess, $1.0 \mathrm{~g}$ of cassava bagasse was added to $25 \mathrm{~mL}$ of distilled water and $0.25 \mathrm{~mL}$ of enzyme Termamyl 240L preparation in a 150.0 $\mathrm{mL}$ erlenmeyer flask. The $\mathrm{pH}$ was adjusted to 5.6 following enzyme data sheet instructions. After covering erlenmeyer flask using aluminum foil paper and rubber band, the sample was kept in a water bath at $90-95^{\circ} \mathrm{C}$ during $25 \mathrm{~min}$. under continuous stirring. Sample was removed from the water bath and the $\mathrm{pH}$ of aqueous medium was adjusted to 9.0 using sodium hydroxide $0.5 \mathrm{~mol} / \mathrm{L}$ in order to stop the enzyme action. The aqueous medium was filtered in Whatman 42 filter paper using a vacuum pump. Solid samples remaining on paper filter was dried in an oven at $60^{\circ} \mathrm{C}$ during 2 days, and then kept in a desiccator over anhydrous calcium chloride.

\section{Thermal Analysis}

Thermal analysis TG (Thermogravimetry), DTA (Differential Thermal Analysis) and DSC (Differential Scanning Calorimetry) curves were 
recorded using a Shimadzu TG 60 and DSC 60, with synthetic air flowing at $100 \mathrm{~mL} / \mathrm{min}$, and a heating rate of $10^{\circ} \mathrm{C} / \mathrm{min}$. and with mass samples of about $6 \mathrm{mg}$. Alumina open sample holder and aluminum sealed crucibles were used for TG/DTA and DSC respectively. TG is used to measure the mass loss either as a function of time (isothermal) or dynamic temperature and controlled atmosphere (Mothé et al., 2006). Endothermic and exothermic changes in a DSC curve indicate events or reactions such as glass transition, gelatinization and melting, occurring during DSC analysis (Habitante et al., 2008).

\section{Microscopy}

Optical microscopy has been widely used by scientists and students as a useful tool to examine objects on a fine scale in order to get information relative to the morphology of the materials examined. After drying, samples of cassava bagasse untreated and treated by acid and enzyme were mounted on standard glass microscope slides. Microscopy analysis was carried out using an Olympus stereo microscope SZX9, with polarization filter and Cybernetic's Cool Snap Pro Color camera. The photographs were identified and scaled using Image Pro Plus.

\section{RESULTS AND DISCUSSION}

\section{Acid Hydrolysis}

Acid hydrolysis has been used to modify starch for over 150 years (Duedahl-Olesen, Pedersen and Larsen, 2000) This process involves suspending starch in an aqueous solution of hydrochloric acid or sulfuric acid at certain temperatures. In the presence of a strong acid and heat, the glycosidic bonds between monosaccharides in a polysaccharide are cleaved. After hydrolysis using concentrated sulfuric acid as agent, from DNS method, it was obtained at $540 \mathrm{~nm}$ an optical density (OD) of $1.59( \pm 0.13)$. Following calibration curve made for DNS reagent, glucose concentration of sample was estimated following as Eq.(1).

$$
\mathrm{RS}(\mathrm{g} / \mathrm{L})=(1,099 \mathrm{OD}+0,017) \mathrm{D}
$$

Where RS is related to reducing sugars concentration in $\mathrm{g} / \mathrm{L}, \mathrm{OD}$ is optical density at 540 $\mathrm{nm}, \mathrm{D}$ is dilution of original hydrolysis solution and other values are related to calibration slope from standard curve. Thus, it was obtained a glucose concentration of $16.97 \mathrm{~g} / \mathrm{L}( \pm 0.66)$ in $100.0 \mathrm{~mL}$ completed with tap water. Considering initial moisture content in Table 1, actually it was converted $1.776 \mathrm{~g}$ of cassava bagasse in dry basis, so each gram produced $0.95 \mathrm{~g} / \mathrm{L}$ of reducing sugars. Stoichiometrically, each $162 \mathrm{~g}$ of starch, incorporates $18 \mathrm{~g}$ of water during hydrolysis, producing $180 \mathrm{~g}$ of glucose, thus there is a convertion factor equals to 1.11. In order to estimate starch content of studied sample it was used (Eq. (2)).

$$
\mathrm{SC}_{1}(\%)=\frac{(100) \mathrm{IGC}}{1.11}
$$

Where $\mathrm{SC}_{1}$ is starch content, IGC is the initial glucose concentration and 1.11 is glucose-starch stoichiometric relation. Following the Eq. (2), cassava bagasse estimated starch content was $84.44 \%$ considering the studied sample. Acid hydrolysis is widely used as a method to determine starch (carbohydrate) content in a sample. However, degradation action is not specific to sugars and some fibrous matter is affected also. Based on reducing sugars, DNS method is not indicated when is needed to identify concentrations of specific carbohydrates with different molecular chain lengths (i.e. mono, di and trisaccharides).

\section{Enzyme Hydrolysis}

According to Duedahl-Olesen, Pedersen and Larsen (2000) and Swinkels (1985) $\alpha$-amylases (Enzyme Classification 3.2.1.1) are endo-acting enzymes that randomly attack the internal $\alpha$-D(1.4) O-glycosidic linkages of starch except for those adjacent to the ends of the substrate and those in the vicinity of branch points. The end products are $\alpha$-limit dextrins, which are branched saccharides not prone to further hydrolysis and malto-oligosaccharides of varying degrees of polymerization (DP), characteristic of the particular enzyme. Basically, starch content in this method was evaluated as difference among soluble fraction after hydrolysis and non soluble remaining material. Using enzyme bacterial $\alpha$ amylase in excess, starch is converted into soluble fractions of maltose and other shorter chains of glucose units also known as dextrins. After drying the remaining material, final mass of $0.102 \mathrm{~g}$ $( \pm 0.016)$ was observed. Considering moisture contents of untreated and hydrolyzed sample 
showed in Table 1, starch content in dry basis was calculated by the (Eq.3).

$\mathrm{SC}_{2}(\%)=(100) \mathrm{FM}-0.89$

Where $\mathrm{SC}_{2}$ is estimated as starch content in sample, FM is final mass or material mass remained on filter paper and 0.89 is related to moisture content. Cassava bagasse sample studied by enzyme hydrolysis has approximately $78.80 \%$ of starch. It is important to note that the use of enzymes can provide besides soluble fraction,the dietary fiber content. Actually, solid product from hydrolysis is mainly fiber and other compounds such as minerals and eventually lipids and others.

Faithfull (1990), studying the determination of starch content in potatoes (Solanum tuberosum) by enzyme hydrolysis observed several disadvantages comparing to the acid hydrolysis procedure. The extraction and hydrolysis process is slower, especially using amyloglucosidase, enzyme activity may vary, reagents are more expensive, and complete hydrolysis is more difficult. Its main advantage is that it is specific, not affecting the cellulosic polysaccharides in the cell walls.

It is important to mention that both methods studied are very quick, useful and low cost procedures. However they have experimental limitations.

\section{Thermal analysis}

Conventional plastics have large impact in increasing the environment's pollution. Thus, the interest has turned towards novel partially and completely biodegradable polymers (Schlemmer, de Oliveira and Salles, 2007). Structural resistance of starches is a very important factor on biodegradable plastics studies and the knowledge regards on blending of starch and polymers. DSC endothermic profile curve, showed in Fig 1, is related to melting event of cassava starch presented in bagasse. The enthalpy required for the event was estimated as $129.16 \mathrm{~J} / \mathrm{g}$ and melting point occurred at $169.36^{\circ} \mathrm{C}$, confirming thermal event result observed previously by Sriroth et al., (2000).

Initial mass losses temperatures are presented in Table 1 and all analyzed samples showed three main mass losses events. Raw cassava bagasse presented was the first one with $11.2 \%$, the second $65.3 \%$ and the third, $19.8 \%$ of mass loss. At the end of the process remains about $1.3 \%$ as a residue.

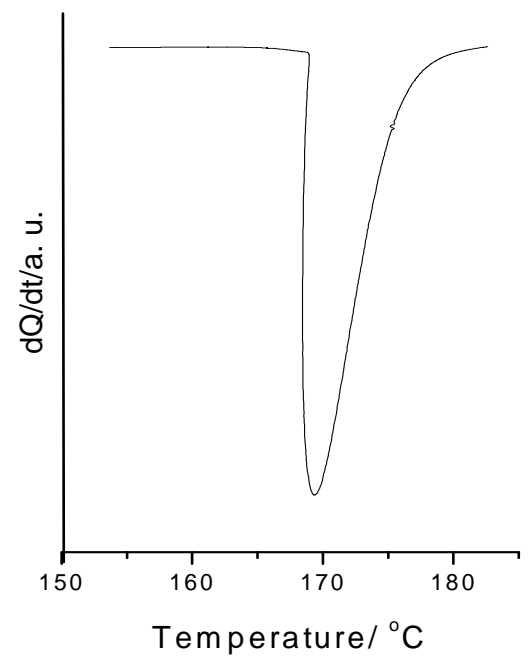

Figure 1 - DSC curve of dry cassava bagasse. 
Table 1 - Thermal degradation of cassava bagasse in untreated state and after hydrolysis process.

\begin{tabular}{cccc}
\hline Cassava bagasse & Untreated $(\mathbf{a})$ & $\begin{array}{c}\text { Submitted to acid } \\
\text { treatment }(\mathbf{b})\end{array}$ & $\begin{array}{c}\text { Submitted to enzyme } \\
\text { treatment }(\mathbf{c})\end{array}$ \\
\hline Moisture $(\%)$ & 11.21 & 5.61 & 9.94 \\
Total mass loss $(\%)$ & 98.27 & 96.34 & 96.02 \\
DTA peak $1\left({ }^{\circ} \mathrm{C}\right)$ & 335.59 & 317.21 & 329.35 \\
DTA peak $2\left({ }^{\circ} \mathrm{C}\right)$ & 442.73 & 448.37 & 465.07 \\
On-set $1\left({ }^{\circ} \mathrm{C}\right)$ & 273.56 & 257.72 & 243.96 \\
On-set $2\left({ }^{\circ} \mathrm{C}\right)$ & 445.87 & 431.49 & 465.31 \\
\hline
\end{tabular}

Cassava bagasse TG curve after acid treatment showed in Fig 2, presents the same three mass losses. The first $5.6 \%$, second $65.7 \%$ and the third 20.9\%. Finally, after $\alpha$-amylase hydrolysis, cassava bagasse presented first loss of $9.94 \%$, the second of $69.4 \%$ and the third of $13.8 \%$ of the total mass. The temperatures were 39.35 to 150 , 246.30 and $458.07^{\circ} \mathrm{C}$.

As described by LeVan (1998) in all TG curves observations, from $30^{\circ} \mathrm{C}$ to $150^{\circ} \mathrm{C}$, mass loss regards to the elimination of moisture content; the second loss occurs between 200 and $400^{\circ} \mathrm{C}$ represents the decomposition of hemi cellulose and cellulose the third loss stage above $400^{\circ} \mathrm{C}$ probably concerns to the decomposition of lignin and ash formation. The hemi cellulose is less stable than the cellulose because its side chains and degrades before cellulose. The lignin degrades throughout hemi cellulose and cellulose degradation processes (Shafizadeh and DeGroot, 1976). Comparing the DTA curves, the peak which represents lignin degradation above $400^{\circ} \mathrm{C}$ is shorter and less acute in the acid treated cassava bagasse than in raw or enzyme hydrolyzed. This variation occurred probably because acid treatment is able to degrade fiber which was not attacked in hydrolysis using enzyme.

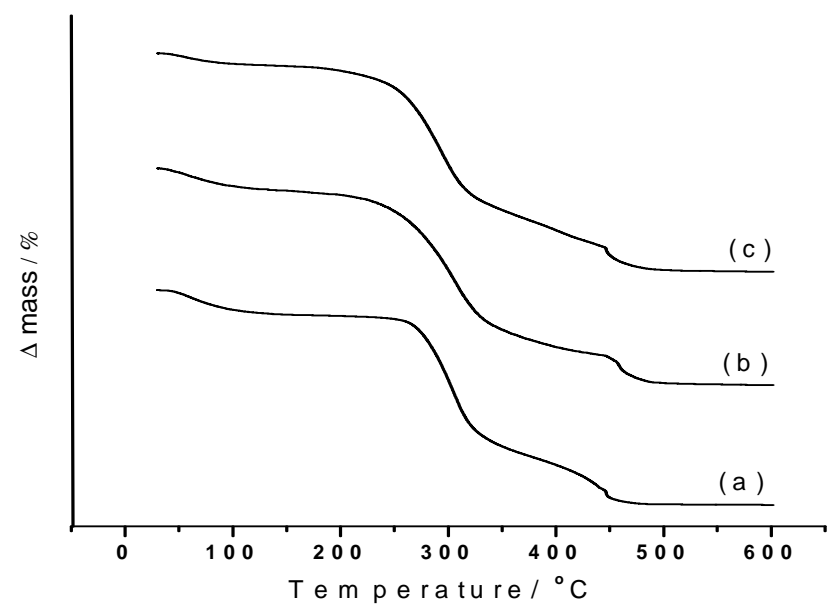

Figure 2 - TG curves of (a) untreated cassava bagasse, (b) acid treated cassava bagasse and (c) cassava bagasse after enzyme hydrolysis.

The TG curve of raw cassava bagasse shows three stages of mass loss. The first stage between $30^{\circ} \mathrm{C}$ and $150^{\circ} \mathrm{C}$ is due to the loss of moisture content which represents $11.19 \%$ of the total mass. The next stage begins at $255.9^{\circ} \mathrm{C}$ and represents the decomposition of hemi cellulose and cellulose bonds and, in addition, for untreated samples complete breakdown of starch (Aggarwal and
Dollimore, 1998; Rudnik et al., 2006). Since next degradation (close to $340^{\circ} \mathrm{C}$ ) does not occur in inert atmosphere, it was supposed that the oxidation of the partially decomposed matter starts TG curves of the acid treated cassava bagasse, shows that the amount of lignin decreased due to the reducing of the degradation peak's. This variation can be explained by the strong and 
randomic acid reaction, breaking more compounds than the enzymatic treatment, which cleaves only starchy material as observed in microscopy. DTA curve of raw cassava bagasse in Fig 3 shows he exothermic peak at $343.13^{\circ} \mathrm{C}$ which is associated to oxidation of cellulose into levoglucosan, water, carbon monoxide and carbon dioxide (Aggarwal and Dollimore, 1998).

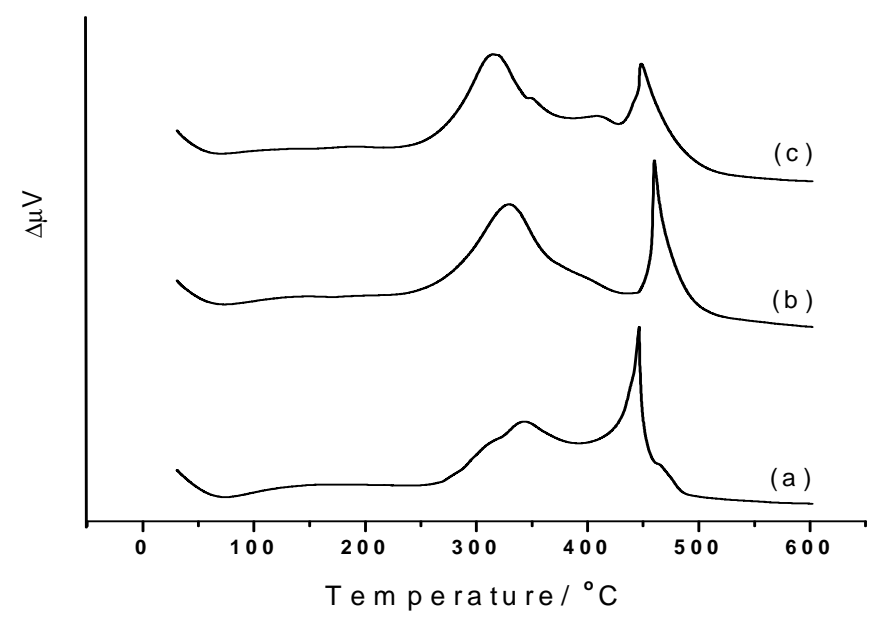

Figure 3 - DTA curves of (a) untreated cassava bagasse, (b) acid treated cassava bagasse and (c) cassava bagasse after enzyme hydrolysis.

Compounds are generated from both cellulose and hemicellulose (hemicellulose is less stable). DTA peak at $446.53^{\circ} \mathrm{C}$ shows the lignin degradation, more specific by breaking (cleaving) carboncarbon bonds. At the end of the process, $1.73 \%$ of residue still remains being related to ashes.

\section{Microscopy}

After microscopic analysis, it can be observed in Fig 4(a) high amount of free cassava starch with its characteristic rounded shape. Besides the presence of a lot of free granules, the untreated material also has fibers with high amount of starch bonded. As previously studied by Leonel, Cereda and Roau (1999) through microscopic observations it is possible to confirm the complete hydrolysis of free starch granules using amylolytic enzyme as showed in Fig 4(b) and the same result was observed using acid treatment. However, cell walls still remains using enzyme and after treatment, some gelatinized starchy material can be present after hydrolysis. Acid treatment can even destroy cell walls as showed in figure 4(c) thus, suggesting that there is not any starch remained after hydrolysis.

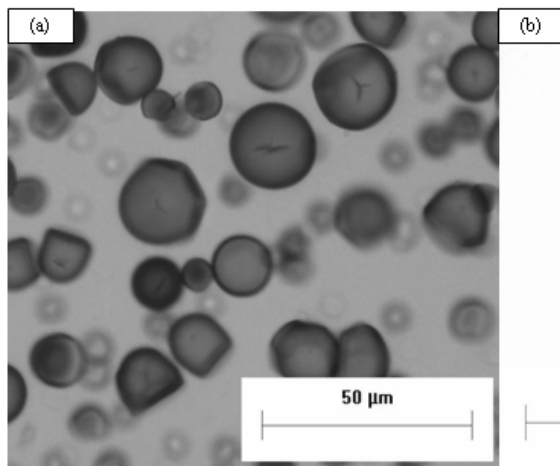

$300 \mu \mathrm{m}$

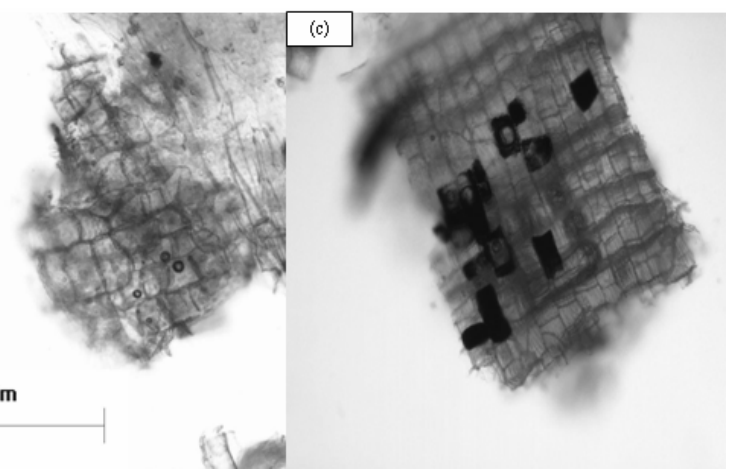

Figure 4 - Photomicrograph of (a) untreated cassava bagasse, (b) acid treated cassava bagasse and (c) cassava bagasse after enzyme hydrolysis. 


\section{CONCLUSIONS}

Through microscopy analysis, it was observed that cassava bagasse hydrolyzed with enzyme $\alpha$ amylase presented cell wall without severe structural changes; however, there still starchy matter in the cells alls even after hydrolysis. Chemical hydrolysis using sulfuric acid leaded to a material critical degradation of both starchy and fibrous matter and due to this action, probably there was not any starch remained. Thermal analysis helped to understand the characterization of all samples of cassava bagasse studied regarding mass losses behaviors as function of temperature increasing. Despite the fact of different starch contents among studied methods, there is a high amount of starch in samples. Thus, the disposal of cassava bagasse concerns on environmental problem and several potential losses of industrial and social opportunities by the use of this residue.

\section{ACKNOWLEDGEMENTS}

The financial resources for the conduction of this study were supported by the project BioAgroPar financed by FINEP, SETI/PR, and Fundação Araucária/PR; and by $\mathrm{CNPq} / \mathrm{Brazil}$. The authors would like to thank the Brazilian Ministry of Education and the Reuni Program.

\section{RESUMO}

As frações nutricionais bem como as propriedades térmicas e outras análises são essenciais para a indústria de alimentos e suas aplicações $\mathrm{O}$ bagaço de mandioca é um importante resíduo agroindustrial e seu teor de amido foi avaliado por dois métodos alternativos. A caracterização por análise térmica e microscopia ajudou na compreensão de como a hidrólise digere a fração amilácea do bagaço de mandioca, $\mathrm{O}$ ponto de fusão foi de $170^{\circ} \mathrm{C}$, a análise termogravimétrica (TG) mostrou após a perda de umidade do material, duas principais perdas de massa em todas as amostras analisadas. Os resultados sugerem que a hidrólise enzimática é menos eficiente na conversão total de amido no bagaço de mandioca. No entanto, o uso de ácido sulfúrico degradou até mesmo a parcela fibrosa do material, afetando as condições de análise.

\section{REFERENCES}

Aggarwall, P. and Dollimore, D. (1998), A thermal analysis investigation of partially hydrolyzed starch. Thermochimica Acta, 319, 17-25.

Cereda, M. P., Vilpoux, O. (2003), Tecnologia, Usos e Potencialidades de Tuberosas Amiláceas Latino Americanas. Fundação Cargill, São Paulo.

Demiate, I. M. (2006), Diário dos Campos. Bagaço de mandioca pode gerar combustível. Available from http://www.diariodoscampos.com.br/20060715/agri.h tm.

Duedahl-Olesen, L., Pedersen, L. H. and Larsen, K. L. (2000), Purification and characterisation of a maltooligosaccharide-forming amylase active at high $\mathrm{pH}$ from Bacillus clausii BT-21. Carbohydrate Research, 329, 97-107.

Faithfull, N. T. (1990), Acid hydrolysis prior to automatic analysis for starch. Journal of the Science of Food and Agriculture, 50, 419-421.

Habitante, A. M. B. Q., Sobral, P.J.A., Carvalho, Solorza-Feria, J. and Bergo, P.V.A. (2008), Phase transitions of cassava starch dispersions prepared with glycerol solutions Journal of Thermal Analysis and Calorimetry, 93, 599-604.

Lacerda, L. G., Carvalho Filho, M. A. S., Bannach, G., Demiate, I. M., Ionashiro, M. and Schnitzler, E. (2008), Thermal behavior of corn starch granules under action of fungal $\alpha$-amilase. Journal of Thermal Analysis and Calorimetry, 93, 445-449.

Lacerda, L. G., Azevedo, J. A. M., Carvalho Filho, M.A.S., Demiate, I.M., Schnitzler, E., Vandenberghe' L.P.S., Soccol, C.R. (2008). Thermal characterization of partially hydrolyzed cassava (Manihot esculenta) starch granules, Brazilian Archives of Biology and Technology, 51, 1209-1215.

Leonel, M., Cereda, M.P. and Roau, X. (1999), Aproveitamento do resíduo da produção de etanol a partir de farelo de mandioca, como fonte de fibras dietéticas. Ciência e Tecnologia de Alimentos, 19, 241-245.

LeVan, S. L. (1998) Thermal Degradation. In: Schniewind. A. P. Concise Encylopedia of Wood and Wood-Based Materials. Elmsford, NY: Pergamon Press. $271-273$.

Milan, K. S. M., Dholakia. H., Tiku, P. K. and Vishveshwaraiah, P. (2008), Enhancement of digestive enzymatic activity by cumin (Cuminum cyminum L.) and role of spent cumin as a bionutrient. Food Chemistry, 110, 678-683.

Miller, G. L. (1959), Use of dinitrosalisylic acid reagent for determination of reducing sugars. Analytical Chemistry, 31, 426-428. 
Mothé, C. G., Carestiato, T., Busnardo, N. G. and Garrido, J. (2006), Estudo termoanalítico do creme anti-celulite à base de Gingko biloba, centella asiática e fucus vesiculosos. In: Congresso Brasileiro de Análise térmica e Calorimetria: ABRATEC, 351.

Mothé , C. G.; Correia, D. Z.; França, F. P. ; Riga, A. T. (2006), Thermal and rheological study of polysaccharides for enhanced oil recovery . Journal of Thermal Analysis and Calorimetry, 85, 31-36.

Pandey A., Soccol C. R., Nigam P., Soccol, V. T. Vandenberghe L. P. S., Mohan R. (2000), Biotechnological potential of agro-industrial residues. II: cassava bagasse. Bioresource Technology, 74, 8187.

Pandey, A., Radhakrishnan, S. (1992), Packed-bed column bioreactor for production of enzyme. Enzyme and Microbial Technology, 14, 486-488.

Pandey, A., Selvakumar, P., Ashakumary, L. (1994), Glucoamylase production by Aspergillus niger on rice bran is improved by adding nitrogen sources. World Journal of Microbiology and Biotechnology, 10, 348-349.

Pandey, A., Soccol, C. R. (1998), Bioconversion of biomass: a case study of ligno-cellulosics, bioconversion in solid state fermentation. Brazillian Archieves of Biology and Technology, 41, 379-389.

Ramachandran, S.; Singh, S. K., Larroche, C., Soccol and C. R., Pandey, A. (2007), Oil cakes and their biotechnological applications - A review Bioresource Technology, 98, 2000-2009.
Rudnik, E., Matuschek, G., Milanov, N. and Kettrup, (2006), Thermal stability and degradation of starch derivatives. Journal of Thermal Analysis and Calorimetry, 85, 267-270.

Schlemmer, D., Oliveira, E.R. and Araújo Sales, M. J. (2007), Journal of Thermal Analysis and Calorimetry, 87, 635-638.

Shafizadeh, F., DeGroot, W. F. (1976) In: Shafizadeh, F., Sarkanen, K. V., Tilman, D. A. Thermal Uses and Properties of Carbohydrates and Lignins. Academic Press, NY, 1-18.

Sriroth, K., Chollakup, R., Piyachomkwan, K., Oates, C.G. (2000), Biodegradable Plastics from Cassava Starch in Thailand, Paper presented at $6^{\text {th }}$ Regional Workshop, 21-25 February, Ho Chi Min City, Vietnam.

Swinkels, J.J.M. (1985), Composition and properties of commercial native starches. Starch/Stärk, 37, 1-5.

Tasun, K., Chose, P. and Ghen, K. (1970). Sugar determination of DNS method. Biotechnology and Bioengineering, 12, 921.

Woiciechowski, A. L., Pandey, A., Machado, C. M. M., Cardoso, E. B., Soccol, C. R. (2000), Hydrolysis of coffee husk: Process optimization to recover its fermentable sugar. In: Sera, T., Soccol, C. R., Pandey, A., Roussos, S. (Org.). Coffee Biotechnology and Quality: Kluwer Academic Publishers. 409-417.

Wurzburg, O.B. (1986), Cross-linking starches. InModified Starches: properties and uses. ed. Boca Raton: CRC Press, pp.41-53. 